\title{
PENGARUH STRATEgI ACE PADA PEMBELAJARAN FISIKA TERHADAP HASIL BELAJAR PESERTA DIDIK KELAS X DI SMA NEGERI 1 PANGKAJENE
}

Bayu Fitra Prisuna

IAIN Pontianak, Kalimantan Barat, Indonesia

Corresponding author email: bayufitraprisuna@iainptk.ac.id

\author{
Info Artikel \\ Diterima: \\ 21 April 2020 \\ Disetujui: \\ 5 Juni 2020 \\ Dipublikasikan: \\ 30 Juni 2020
}

\begin{abstract}
Abstrak:
Penelitian ini bertujuan untuk mengetahui pengaruh strategi $A C E$ (Activities, Class Discussion, Exercise) terhadap hasil belajar fisika pada peserta didik di SMA Negeri 1 Pangkajene. Jenis penelitian ini quasi experimental. Sampel penelitian ini adalah kelas X MIA1 sebanyak 27 orang sabagai kelas eksperimen dan kelas X MIA2 sebanyak 27 orang sebagai kelas kontrol. Instrumen penelitiannya adalah tes hasil belajar peserta didik. Uji hipotesis dilakukan dengan uji-t. Hasil penelitian menunjukkan bahwa hasil belajar kelas eksperimen berada di kategori tinggi sedangkan kelas kontrol berada di kategori sedang. Berdasarkan hasil uji hipotesis dapat disimpulkan bahwa perbedaan yang signifikan antara hasil belajar kelompok yang diajar menggunakan strategi $A C E$ dengan kelompok yang diajar dengan pembelajaran konvensional.
\end{abstract}

Kata Kunci: Strategi $A C E$, Hasil belajar

\begin{abstract}
:
The purpose of this research was to know the effect of ACE strategy (Activities, Class Discussion, Exercise) toward students achievement in physics learning at SMA Negeri 1 Pangkajene. The type of this research was quasi experimental. The sample of this research was X MIAl class as experimental class (27 students) and X MIA 2 class as the control class (27 students). The research instrument is a student learning achievement test. The hypothesis test was done with the t-test. The result showed that students achievement in physics learning at experimental class have high category, meanwhile students achievement in physics learning at control class has medium category. Based on the hypothesis test can be concluded that there are significant different between a group who was taught by using the ACE strategy and the group who was taught by using conventional learning method.
\end{abstract}

Keyword: Strategy ACE, learning outcomes

\section{Pendahuluan}

Pendidikan berasal dari kata "didik", lalu kata ini mendapat awalan "me" sehingga menjadi "mendidik" artinya, memelihara dan memberi latihan.Dalam memelihara dan memberi latihan diperlukan adanya ajaran, tuntunan, dan pimpinan mengenai akhlak dan kecerdasan pikiran (Syah, 2010). Akan tetapi pada zaman ini pendidikan di Indonesia menuntut guru menggunakan paradigma baru dalam pembelajaran yaitu paradigma Student Oriented yang bercirikan: (1) peserta didik aktif; (2) peserta didik mengkonstruksikan sendiri pengetahuannya; (3) peserta didik menemukan; (4) peserta didik berusaha menyelesaikan didalam kelompok; (5) peserta didik bebas memilih model representasi yang sesuai dengan struktur kognitifnya (Muliawan, 2014). Sejalan dengan UU No. 20 tahun 2003 tentang Sistem Pendidikan Nasional, Pendidikan adalah usaha sadar dan terencana untuk mewujudkan 
suasana belajar dan proses pembelajaran agar peserta didik secara aktif mengembangkan potensi dirinya untuk memiliki kekuatan spiritual keagamaan, pengendalian diri, kepribadian, kecerdasan, akhlak mulia, serta keterampilan yang diperlukan dirinya dan masyarakat.

Pembelajaran itu sendiri merupakan proses interaksi antara peserta didik dengan lingkungannya yang menyebabkan perubahan perilaku ke arah yang lebih baik. Menurut Arifin (2010: 10), "pembelajaran merupakan suatu proses atau kegiatan yang sistematis dan sistemik yang bersifat interaktif dan komunikatif antara pendidik "guru" dengan siswa, sumber belajar, dan lingkungan untuk menciptakan suatu kondisi yang memungkinkan terjadinya tindakan belajar siswa". Pembelajaran Fisika terdiri dari banyak konsep dan prinsip yang pada umumnya sangat abstrak."Fisika adalah mata pelajaran yang banyak menuntut intelektualitas yang relatif tinggi sehingga sebagian besar peserta didik mengalami kesulitan mempelajarinya" (Mundilarto, 2002: 5).Kesulitan yang banyak dihadapi oleh sebagian besar siswa adalah dalam menginterpretasi berbagai konsep dan prinsip Fisika.

Sebagai salah satu contoh adalah hasil belajar peserta didik di SMA Negeri 1 Pangkajene, khususnya dalam pembelajaran fisika masih rendah. Pernyataan ini peneliti dapatkan dari observasi awal dan wawancara dengan guru fisika yang dilakukan pada tanggal 23 juli 2015. Hal ini dapat dilihat dari pelaksanaan pembelajaran itu sendiri yang masih didominasi oleh paradigma Teacher Oriented. Proses pembelajaran fisika di kelas X SMA Negeri 1 Pangkajene pada umumnya hanya menekankan pada peserta didik untuk mengetahui teori dan rumus yang ada tanpa mencoba mengarahkan peserta didik lebih aktif untuk mencari tau kemudian menghubungkan dengan fenomena-fenomena yang ada dikehidupan sehari-hari. Peserta didik hanya lebih sering mendengarkan, menerima, dan mencatat apa yang disampaikan guru tanpa ada timbal balik untuk peserta didik lebih proaktif mengajukan pertanyaan, mengajukan pendapat, dan saling diskusi untuk pemecahan masalah.

Sudjana (2002) menyatakan bahwa kegiatan pembelajaran yang berpusat pada guru menekankan pentingnya aktivitas guru dalam membelajarkan peserta didik. Peserta didik berperan sebagai pengikut dan penerima pasif dari kegiatan yang dilaksanakan. Ciri pembelajaran ini adalah: (1) dominasi guru dalam kegiatan pembelajaran, sedangkan peserta didik bersifat pasif dan hanya melakukan kegiatan melalui perbuatan pendidik, (2) bahan belajar terdiri atas konsep-konsep dasar atau materi belajar yang tidak dikaitkan dengan pengetahuan awal siswa sehingga peserta didik membutuhkan informasi yang tuntas dan gamblang dari guru, (3) pembelajaran tidak dilakukan secara berkelompok dan (4) pembelajaran tidak dilaksanakan melalui kegiatan laboratorium. Sejalan dengan Tukimun (2006) dalam penelitiannya menyatakan bahwa pembelajaran yang masih bersifat teacher centered, menyebabkan suasana belajar yang kurang menarik dan kurang komunikatif. Hal ini dapat menyebabkan rendahnya hasil belajar siswa.

Ada beberapa hal yang di identifikasi sebagai faktor penyebab rendahnya hasil belajar fisika peserta didik di SMA Negeri 1 Pangkajene, yaitu :

(1) karena fisika dianggap sulit dan tidak menyenangkan bagi peserta didik. Fisika dianggap sulit karena di penuhi rumus-rumus dan angka-angka yang membingungkan. (2) pembelajaran masih berpusat pada guru, sehingga pengetahuan masih ditransformasikan utuh dari pikiran guru ke pikiran peserta didik. (3) aktivitas dalam pembelajaran peserta didik masih rendah. Peserta didik yang aktif adalah peserta didik yang pintar, sedangkan peserta didik yang kurang pintar cenderung pasif. (4) kemauan bertanya dan rasa ingin tahu peserta didik sangat kurang karena pengetahuan awal fisika peserta didik relatif masih kurang. Sehingga peserta didik kesulitandalam mnyelesaikan suatu permasalahan fisika. (5) peserta didik maluuntuk bertanya kepada guru. Hal ini disebabkan peserta didik takut dianggap "bodoh" jika bertanya. (6) interaksi dan kerja sama peserta didik masih kurang. Peserta didik yang pintar cenderung memiliki sifat individualisme dan sebaliknya peserta didik yang kurang pintar enggan bertanya kepada peserta didik yang lebih mampu.

Melaksanakan kegiatan belajar dan pembelajaran yang efektif tidaklah mudah. Dalam kondisi seperti itu, diperlukan peran aktif siswa dalam proses pembelajaran. Guru harus memiliki sejumlah strategi yang digunakan untuk mencapai tujuan belajar dan pembelajaran yang telah ditetapkan sebelumnya. Salah satu strategi yang dapat digunakan dengan kondisi nyata yang dihadapi dilapangan adalah strategi ACE (Activities, Class discussion, Exercise). Strategi ACE merupakan implementasi pembelajaran berdasarkan teori APOS (Action, Process, Object, Schema) yang telah dikembangkan oleh penelitidi Amerika Serikat (RUMEC). Strategi $A C E$ mencakup tiga langkah kegiatan belajar yaitu aktivitas, dikusi kelas dan latihan (Asiala, et al., 1996). Strategi ACE memberikan para peserta didik untuk belajar secara sistematis, efektif dan efesien dalam menghadapi berbagai bahan ajar. (Nurlaelah 
\& Usdiyana: 2005)

Berdasarkan pemikiran tersebut, penelitian bertujuan untuk mengetahui perbedaan hasil belajar fisika antara kelompok yang belajar menggunakan strategi ACE dan kelompok yang belajar dengan pembelajaran konvensional pada peserta didik SMA Negeri 1 Pangkajene tahun ajaran 2015/2016.

\section{Metode Penelitian}

Jenis Penelitian

Jenis penelitian ini adalah quasi experiment yang menggunakan desain non equivalen control group design.

Waktu dan Tempat Penelitian

Penelitian ini dilaksanakan di kelas X SMA Negeri 1 Pangkajene pada semester ganjil bulan Agustus sampai Oktober tahun ajaran 2015/2016.

Populasi dan Sampel Penelitian

Populasi dalam penelitian ini adalah seluruh peserta didik kelas X MIA SMA Negeri 1 Pangkajene pada tahun pelajaran 2015/2016, yang terdiri dari 6 kelas dengan jumlah 180 orang peserta didik. Pengambilan sampel dilakukan dengan cara cluster random sampling dengan mengambil 2 kelas secara acak dan diperoleh kelas X MIA 1 (27 peserta didik) sebagai kelas eksperimen dan X MIA 2 (27 peserta didik) sebagai kelas kontrol.

Prosedur Penelitian

Data yang diperoleh dari hasil penelitian ini semuanya diolah dan dianalisis dengan teknik statistik inferensial. Teknik analisis inferensial digunakan untuk menguji perbedaan hasil belajar fisika pada kedua kelas penelitian dan menjawab hipotesis penelitian yang diajukan. Pengujian hipotesis ini menggunakan uji dua pihak dengan uji-t. Sebelum dilakukan pengujian hipotesis penelitian, terlebih dahulu dilakukan uji normalitas dan uji homogenitas varians. Pengujian hipotesis dimaksudkan untuk menjawab hipotesis yang telah diajukan. Desain penelitian ditunjukkan pada gambar 1 (Sugiyono, 2009).

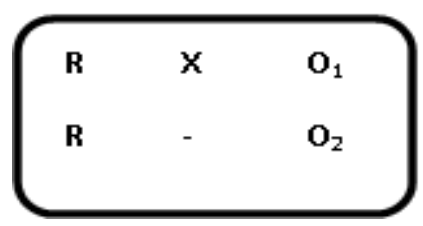

Keterangan :

Gambar 1. Desain non equivalen control group

$\mathrm{R}=$ menyatakan pengacakan

$\mathrm{X} \quad=$ pembelajaran fisika dengan menggunakan strategi $A C E$ (Perlakuan pada kelas eksperimen)

- $\quad$ : pembelajaran fisika dengan pembelajaran konvensional (Perlakuan pada kelas kontrol)

$\mathrm{O}_{1} \quad$ : tes hasil belajar fisika setelah menggunakan strategi $A C E$ pada kelas eksperimen

$\mathrm{O}_{2} \quad$ : tes hasil belajar fisika dengan pembelajaran konvensional pada kelas control

Teknik dan Alat Pengumpulan Data

Teknik pengumpulan data yang digunakan dalam penelitian ini adalah menggunakan tes hasil belajar peserta didik yang dikembangkan oleh peneliti, dan telah diujicobakan untuk mengetahui validitas serta reliabilitasnya sebelum digunakan.

Uji Validitas

Pengujian validitas dimaksudkan untuk mengetahui tingkat kevalidan instrumen yang akan digunakan dalam pengumpulan data, sehingga data yang diperoleh akan menjadi akurat. Untuk perhitungan validitas digunakan persamaan 1 (Arikunto, 2013) di bawah ini.

$$
\gamma_{p b i}=\frac{M_{p}-M_{t}}{s_{t}} \sqrt{\frac{p}{q}}
$$


Keterangan

$\gamma_{p b i} \quad=$ koefisien korelasi biserial

$M_{p} \quad$ = rerata skor dari subjek yang menjawab benar bagi item yang dicari validitasnya

$M_{t} \quad=$ rerata skor total

$S_{t} \quad=$ standar deviasi dari skor total proporsi

$\mathrm{P} \quad=$ proporsi siswa yang yang menjawab benar

$\mathrm{q}=$ proporsi siswa yang menjawab salah $(\mathrm{q}=1-\mathrm{p})$

Kriteria Pengujian:

Jika: $\gamma_{p b i} \geq \mathrm{r}_{\text {tabel }}$, maka item dinyatakan valid.

Jika: $: \gamma_{p b i} \leq \mathrm{r}_{\text {tabel, }}$ maka item dinyatakan drop.

Sehingga soal yang digunakan pada saat penelitian hanya item soal yang valid saja.

Uji Reliabilitas

Untuk pengujian reliabilitas item digunakan rumus K.R. 20 dengan persamaan 2 dan 3 (Arikunto, 2013).

$$
r_{11}=\left(\frac{n}{n-1}\right)\left(\frac{S^{2}-\sum p q}{S^{2}}\right)
$$

dimana,

$$
S=\sqrt{\frac{\sum X^{2}-\frac{\left(\sum X\right)^{2}}{N}}{N}}
$$

\section{Keterangan}

$\mathrm{r}_{11} \quad=$ realibilitas tes secara keseluruhan

$\mathrm{p} \quad=$ proporsi subjek yang menjawab item dengan benar

$\mathrm{q}=$ proporsi subjek yang menjawab item dengan salah $(\mathrm{q}=1-\mathrm{p})$

$\sum p q=$ jumlah hasil perkalian antara $\mathrm{p}$ dan $\mathrm{q}$

$n \quad$ = banyaknya item

$\mathrm{S} \quad=$ standar deviasi dari tes (standar deviasi adalah akar varians)

Teknik Analisis Data

Teknik analisis data yang digunakan dalam penelitian ini adalah analisis inferensial. Analisis inferensial digunakan untuk menguji perbedaan hasil belajar fisika pada kedua kelas penelitian dan menjawab hipotesis penelitian yang diajukan. Pengujian hipotesis ini menggunakan uji dua pihak dengan uji-t. Sebelum dilakukan pengujian hipotesis penelitian, terlebih dahulu dilakukan uji normalitas data dan uji homogenitas varians.

\section{Hasil Penelitian dan Pembahasan}

Skor hasil belajar fisika yang diperoleh peserta didik diukur menggunakan instrumen tes dalam bentuk soal pilihan ganda dengan jumlah soal yang terdiri atas 25 nomor sehingga skor terendah yang dapat diperoleh peserta didik adalah 0 dan skor tertinggi yang dapat diperoleh peserta didik adalah 25, tes yang diberikan berupa tes hasil belajar fisika dalam ranah kognitif yang mengacu pada indikator pencapaian hasil belajar peserta didik. Perolehan skor hasil belajar fisika peserta didik, antara kelas eksperimen yang diajar strategi $A C E$, dan kelas kontrol yang diajar dengan pembelajaran konvensional. Data tes hasil belajar fisika peserta didik kelas X SMA Negeri 1 Pangkajene yang diajar menggunakan strategi $A C E$ disajikan pada tebel 1.

Tabel 1. Statistik deskriptif hasil belajar fisika peserta didik kelas X SMA Negeri 1 Pangkajene

\begin{tabular}{lcc}
\hline \multicolumn{1}{c|}{ Statistik } & Kelas Eksperimen & Kelas Kontrol \\
\hline Jumlah Sampel & 27 & 27 \\
Skor tertinggi & 24 & 20 \\
Skor terendah & 8 & 10
\end{tabular}




\begin{tabular}{lc|c}
\hline \multicolumn{1}{c|}{ Statistik } & Kelas Eksperimen & Kelas Kontrol \\
\hline Rentang skor & 16 & 10 \\
Skor tertinggi ideal & 25 & 25 \\
Skor terendah ideal & 0 & 0 \\
Jumlah kelas interval & 6 & 6 \\
Panjang kelas & 3 & 2 \\
Skor rata-rata & 16,78 & 14,94 \\
Standar deviasi & 4,72 & 3,52 \\
\hline
\end{tabular}

Berdasarkan Tabel 1 terlihat bahwa hasil belajar fisika yang diperoleh pada kelas eksperimen lebih tinggi dibandingkan hasil belajar yang diperoleh peserta didik pada kelas kontrol. Pada kelas eksperimen skor rata-rata 16,78, skor tertinggi yang dicapai 24 dan skor terendahyang dicapai 8 . Sedangkan pada kelas kontrol diperoleh skor rata-rata14,94, skor tertinggi 20 dan skor terendah 10. Skoridealtertinggi pada kedua kelas 25 danskorideal terendah adalah 0.Standar deviasi yang diperoleh pada kelas eksperimen yaitu 4,72 sedangkan pada kelas kontrol diperoleh 3,52.

Adapun data distribusi frekuensi dan pengkategorian hasil belajar peserta didik SMA Negeri 1 Pangkajene pada kelas eksperimen dan kelas kontrol dapat dilihat pada tabel 4.2 dan 4.3

Tabel 2. Distribusi frekuensi hasil belajar fisika peserta didik pada kelas eksperimen

\begin{tabular}{cccc}
\hline Rentang & Kategori & \multicolumn{2}{c}{ Kelas eksperimen } \\
\cline { 3 - 4 } skor & & Frekuensi & Persentase (\%) \\
\hline $20-25$ & Sangat tinggi & 7 & 25,93 \\
$15-19$ & Tinggi & 11 & 40,74 \\
$10-14$ & Sedang & 8 & 29,63 \\
$5-9$ & Rendah & 1 & 3,70 \\
$0-4$ & Sangat rendah & 0 & 0 \\
\hline
\end{tabular}

Tabel 3. Distribusi frekuensi hasil belajar fisika peserta didik pada kelas kontrol

\begin{tabular}{cccc}
\hline Rentang & Kategori & \multicolumn{2}{c}{ Kelas kontrol } \\
\cline { 2 - 4 } skor & & Frekuensi & Persentase (\%) \\
\hline $20-25$ & Sangat tinggi & 4 & 14,82 \\
$15-19$ & Tinggi & 11 & 40,74 \\
$10-14$ & Sedang & 12 & 44,44 \\
$5-9$ & Rendah & 0 & 0 \\
$0-4$ & Sangat rendah & 0 & 0 \\
\hline
\end{tabular}

Untuk lebih jelasnya dapat dilihat pada histogram seperti pada gambar 1 berikut ini.

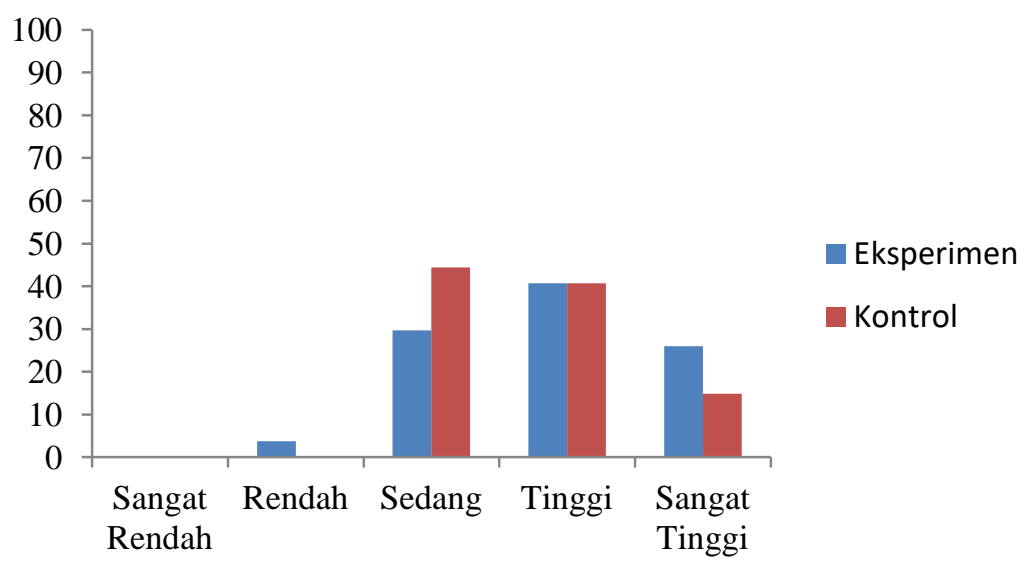

Gambar 1. Diagram persentase skor hasil belajar fisika peserta didik kelas eksperimen dan kontrol 
Data yang diperoleh dari penelitian ini dianalisis secara inferensial dengan uji-t pada taraf signifikan $\alpha=0,05$. Syarat yang harus dipenuhi untuk pengujian hipotesis adalah data yang diperoleh harus berdistribusi normal serta mempunyai variansi yang homogen.Oleh karena itu sebelum dilakukan uji-t terlebih dahulu dilakukan uji normalitas dan uji homogenitas terhadap hasil belajar fisika peserta didik untuk kelas eksperimen dan kelas kontrol.

Uji normalitas dilakukan dengan menggunakan uji Chi-Kuadrat, hasil pengujian normalitas pada skor hasil belajar fisika dapat dilihat pada tabel 4.4 berikut:

Tabel 4. Hasil pengujian normalitas hasil belajar fisika kelas eksperimen dan kontrol

\begin{tabular}{lllll}
\hline Skor & $\chi_{\text {hitung }}^{2}$ & $\mathrm{~A}$ & $\mathrm{Dk}$ & $\chi_{\text {tabel }}^{2}$ \\
\hline Eksperimen & 6,178 & 0,05 & 3 & 7,815 \\
Kontrol & 7,215 & 0,05 & 3 & 7,815 \\
\hline
\end{tabular}

Pada tabel 4 dapat dilihat bahwa dari hasil perhitungan untuk kelas eksperimen yang diajar menggunakan strategi $A C E$ diperoleh pada kelas eksperimen $X_{\text {hitung }}^{2}=6,178$ dan $X_{\text {tabel }}^{2}=x_{(0,95)(3)}^{2}=$ 7,815. Dengan demikian $x_{\text {hitung }}^{2}<x_{\text {tabel }}^{2}$ yaitu $6,178<7,815$ yang artinya skor hasil belajar fisika peserta didik berasal dari populasi yang berdistribusi normal. Data selengkapnya dapat dilihat pada lampiran B. Untuk kelas kontrol yang diajar dengan pembelajaran konvensional diperoleh $X^{2}$ hitung $=$ 7,215 dan $X_{\text {tabel }}^{2}=X_{(0,95)(5)}^{2}=7,815$. Dengan demikian $x_{\text {hitung }}^{2}<x_{\text {tabel }}^{2}$ yaitu $7,215<7,815$ yang artinya skor hasil belajar fisika peserta didik berasal dari populasi yang berdistribusi normal. Karena data yang diperoleh dari populasi berdistribusi normal, maka dilanjutkan dengan uji homogenitas varians populasi. Hasil pengujian homogenitas varians data hasil belajar fisika menggunakan uji $\mathrm{F}$ dengan taraf nyata $\alpha=0,05$ diperoleh bahwa nilai $F_{\text {hitung }}$ dan $F_{\text {tabel }}$ untuk hasil belajar fisika, $\mathrm{F}_{\text {hitung }}<\mathrm{F}_{\text {tabel }}$ yaitu $1,79<1,95$ yang artinya data dalam penelitian ini berasal dari populasi yang homogen. Pengujian hipotesis dimaksudkan untuk menjawab hipotesis yang telah diajukan. Pengujian hipotesis ini menggunakan uji dua pihak dengan uji-t.

Berdasarkan hasil pengujian hipotesis diperoleh bahwa untuk hasil belajar fisika nilai $t_{\text {hitung }}>$ $\mathrm{t}_{\text {tabel }}$ yaitu 3,33> 2,03 maka keputusanya $\mathrm{H}_{0}$ ditolak dan $\mathrm{H}_{1}$ diterima, artinya terdapat perbedaan yang signifikan antara hasil belajar fisika peserta didik yang diajar menggunakan strategi $A C E$ dan yang diajar dengan pembelajaran konvensional pada kelas X SMA Negeri 1 Pangkajene tahun ajaran $2015 / 2016$.

Hasil penelitian menunjukkan bahwa ada pengaruh yang signifikan menggunakan strategi $A C E$ pada pembelajaran fisika terhadap hasil belajar peserta didik kelas X di SMA Negeri 1 Pangkajene. Hasil penelitian terhadap kelas eksperimen menggunakan strategi $A C E$ pada pembelajaran fisika terhadap hasil belajar peserta didik kelas X di SMA Negeri 1 Pangkajene menunjukkan adanya peningkatan hasil belajar yang signifikan. Hal ini ditunjukkan dengan meningkatnya skor rata-rata hasil belajar fisika kelas eksperimen sebesar 16,78 dan persentase skor hasil belajar yang berada pada kategori sangat tinggi sebesar 25,93. Sedangkan skor rata-rata hasil belajar fisika kelas kontrol sebesar 14,94 dan persentase skor hasil belajar yang berada pada kategori sangat tinggi sebesar 14,82.

Berdasarkan uraian di atas, maka hasil penelitian ini menunjukkan terdapat perbedaan yang signifikan antara hasil belajar fisika peserta didik yang diajar menggunakan strategi $A C E$ dan yang diajar dengan pembelajaran konvensional pada kelas X SMA Negeri 1 Pangkajene tahun ajaran $2015 / 2016$. Adanya perbedaan hasil belajar yang signifikan antara kelas eksperimen dan kelas kontrol disebabkan oleh penggunaan strategi $A C E$ pada kelas eksperimen.

Pembelajaran menggunakan strategi $A C E$ dengan meliputi tahapan kegiatan aktivitas, kelas diskusi dan latihan mampu mengarahkan peserta didik lebih aktif dalam proses pembelajaran serta lebih cakap menyelesaikan suatu permasalahan dalam proses pembelajaran.

Penelitian ini juga sejalan dengan Selamat (2009) dalam penelitian berjudul Implementasi Pembelajaran Kooperatif Berpendekatan Siklus ACE Berbantuan LKM untuk Meningkatkan Kualitas Pembelajaran Kimia Analitik Kuantitatif mengemukakan Pembelajaran dengan menggunakan strategi $A C E$ dapat meningkatkan aktivitas dan prestasi belajar siswa. Implementasi strategi $A C E$ menjadikan suasana belajar berlangsung dengan aktivitas belajar yang tinggi. Siswa sangat antusias dalam belajar yang ditunjukkan oleh perhatiannya selama pembelajaran.Pada saat diskusi kelompok dan kelas siswa tidak takut bertanya mapun menjawab permasalahan yang diberikan baik kepada atau dari guru 
maupun temannya.

Dari uraian diatas, pembelajaran dengan strategi $A C E$ ketika dilakukan dengan maksimal akan memberikan peluang yang lebih besar kepada peserta didik untuk memahami mata pelajaran fisika lebih luas dan mendalam dengan proses pembelajaran yang lebih mengarahkan kepada student oriented. Dan fisika tidak lagi menjadi momok menakutkan bagi peserta didik. Maka guru dituntut mempunyai kompetensi dalam hal merancang suatu strategi pembelajaran fisika sehingga menjadi suatu hal yang lebih menarik untuk dipelajari oleh peserta didik.

\section{Simpulan}

Berdasarkan hasil penelitian dapat disimpulkan bahwa terdapat perbedaan yang signifikan antara hasil belajar fisika kelompok yang belajar menggunakan strategi $A C E$ dan yang belajar dengan pembelajaran konvensional pada peserta didik kelas X SMA Negeri 1 Pangkajene tahun ajaran 2015/2016. Rerata hasil belajar fisika peserta didik yang mengikuti pembelajaran dengan strategi ACE memiliki kategori tinggi, sedangkan yang mengikuti pembelajaran konvensional memiliki kategori sedang. Peneliti merekomendasikan strategi $A C E$ agar dapat diterapkan dalam pembelajaran fisika di kelas sehingga dapat meningkatkan hasil belajar.

\section{Referensi}

Arifin, Z. (2010). Evaluasi Pembelajaran. Bandung: PT Remaja Rosdakarya.

Arikunto, S. (2013). Dasar-Dasar Evaluasi Pendidikan. Jakarta: Bumi Aksara.

Asiala, M. \& et al. (1996). A framework for research and curriculum development in undergraduate mathematics education, Research in Collegiate Mathematics Education II, CBMS Issues in Mathematics Education,6 (1), 32.

Muliawan, I. K., Syahruddin, H., \& Suarjana, I. M. (2014). Pengaruh Model Pembelajaran Kooperatif Tipe Script dengan Siklus ACE Terhadap Hasil Belajar. e-Jurnal Mimbar PGSD Universitas Pendidikan Ganesha,2 (1), 2.

Mundilarto. (2002). Kapita Selekta Pendidikan Fisika. Yogyakarta: FMIPA UNY.

Nurlaelah, E., \& Usdiyana, D. (2005). Inovasi Pembelajaran Struktur Aljabar I dengan Menggunakan Program ISETL Berdasarkan Teori APOS. Jurnal Pengajaran MIPA,2 (1), 7.

Selamat. (2009). Implementasi Pembelajaran Kooperatif Berpendekatan Siklus ACE Berbantuan LKM untuk Meningkatkan Kualitas Pembelajaran Kimia Analitik Kuantitatif. Jurnal Pendidikan dan Pengajaran,42 (1), 37-43.

Sudjana, N. (2002). Dasar-Dasar Proses Belajar Mengajar. Bandung: Sinar Baru Algensindo.

Sudjana, N. (2005). Metoda Statistika. Bandung: Tarsito.

Sugiyono. (2012). Metode PenelitianPendidikan. Bandung: Alfabeta.

Syah, M. (2010). Psikologi Pendidikan. Bandung: PT Remaja Rosdakarya offset.

Tukimun. (2006). Pengaruh Model Pembelajaran Konstruktivis Melalui Penerapan Pembelajaran Timbal-Balik dan Kemampuan Berpikir Matematis Terhadap Hasil Belajar Fisika Siswa Kelas X SMA Negeri 1 Binjai. Tesis, dipublikasikan. Universitas Negeri Medan. 